\title{
Rickettsia typhi
}

National Cancer Institute

\section{Source}

National Cancer Institute. Rickettsia typhi. NCI Thesaurus. Code C86725.

A species of aerobic, Gram negative, rod and cocci shaped bacteria assigned to the phylum Proteobacteria. This species is obligately intracellular, motile and transmitted to humans by a tick or flea host. R. typhi is a pathogen that causes murine typhus. 